\title{
Comparative Analysis of Melodic Variation of Concession Clauses with Two or More Syntagms in English and Azerbaijani
}

\author{
Rana Hasanova ${ }^{1}$ \\ ${ }^{1}$ Department of English Grammar, Azerbaijan University of Languages, Baku, Azerbaijan \\ Correspondences: Rana Hasanova, 511 quarter, house 18a, flat 62, Alasgar Alakbarov str, Az. 1073, Baku, \\ Azerbaijan. E-mail: m.rena.2009@mail.ru
}

Received: July 3, 2015 Accepted: July 21, 2015 Online Published: September 29, 2015

doi:10.5539/ijel.v5n5p110 URL: http://dx.doi.org/10.5539/ijel.v5n5p110

\begin{abstract}
The article is devoted to the problem of comparative analysis of melodic variation of concession clauses with two or more syntagms in English and Azerbaijani. The research has been done on the basis of comparative-typological and experimental-phonetic methods, as both of the languages belong to different language families and they have different language systems. A lot of sentences from both languages have been chosen to carry out the experiment. A great attention has been paid to the sentences with two-syntagms and three-syntagms depending on the purpose of the research. After getting the results of experiment, the part of material belonging to English has been compared with the part that belongs to Azerbaijani. For this purpose PRAAT computer program has been used.
\end{abstract}

Keywords: variation, concession, melody, acoustic, parameters, intonation, communication

\section{Introduction}

Application of experimental-phonetic method in learning the sentence intonation gives an opportunity to express certain ideas about its characteristic features and to describe it visually. The prosodic structure of a sentence is formed on the combination of acoustic parameters, such as the development of the tone, the strength of the voice, the development of the pronunciation speed, tembre and pause. Acoustic characteristic of intonation is formed by the frequency, the vibration amplitude of vocal cords, muscle strenght of speech organs and different pronunciation timbers.

\section{Scope of the Study}

In modern linguistics experimental or experimental-phonetic methods play an important role. Thanks to experimental research works there were found links between grammar and phonetics. So, the topic of the article being directly connected with grammar and phonetics, we have had to look through different viewpoints of specialists. One of the Russian linguists Peshkovskiy in his researches expressed his attitude to the relationship between syntactic constructions and intonation. From his viewpoint intonation is a helping syntactic means. It is evident that in linguistics, the thought "intonation and grammatical means compensate each-other in the formation of a sentence" belongs just to him. He writes:

"The more clearly any syntactic meaning is expressed, the weaker its expression by means of intonation can be, and visa-versa, when the intonation expression is stronger, the grammatical expression becomes weaker." (Peshkovskiy, 1960).

According to Scherba the syntax of communicative aspect consists of the absolute presence of the use of intonation in the formation of a sentence (Scherba, 1974). In this research Scherba's theoretical proposition "the intonation is a complex phonetic phenomenon and it is in close connection with syntactic constructions" has been referred to.

In the article intonation characteristics of a sentence is said to be closely connected with its semantic-syntactic structure. The most successful way of deterining similar and different intonation characteristics of compared concession clauses with two or more syntagms in English and Azerbaijani is carrying out an experimental-phonetic research, taking into consideration the semantic-syntactic structure and stylistic characteristic of the same sentence types. The syntagmatic structure of a sentence is very important in the analysis of intonation characteristics of a sentence. It is also of great importance if a sentence is one-syntagm or 
multi-syntagms, if a syntagm is used in pre- or post position, if a syntagm is complete from semantic poin of view and so on.

In Post-Soviet linguistics Scherba's viewpoints of syntagm as a main intonation unit are spread widely. The interpretation of a syntagm as a semantic-syntactic-phonetic unit belongs to him. The mutual influence of intonation and syntactic units in the research of prosodic features of utterance should be paid a special attention. In this case to determine some centers of sentence bearing meaning is a very important matter. By including syntagm in the other speech units we should admit that it is a main communicative unit. During the speech act any sentence is divided into small wholes from the point of view of intonation and meaning. Such units are called syntagm by Scherba (Scherba, 1958).

In Scherba's syntagm theory, shortages of syntactic and phisiological criteria of speech act were liquidate. (Scherba, 1958). Scherba accepted the syntagm as a combination of menaing and material expression. He wrote:

"I call the phonetic unit which expresses semantic unity, consisting of both one rhythmic group and combination of some of them formed in speech-thought process, a syntagm." (Scherba, 1958).

According to Scherba syntagm consists of words, word cobinations and even group of word combinations, too. Syntagm is not only able to part from the utterance, but it also forms them. In case syntagms can be separated from utterance, its being added to speech level is quite natural. In comparison with words and word combinations, syntagm is not constant, unchangable in speech, it is a variational structure. Only in speech context syntagm acquires full meaning. The meaning of the syntagm depends on the menaing of the whole, and its semantics can change depending on the intention of the speaker. The main feature of syntagmatic division of the sentence is that a syntagm is indivisible from intonation point of view. In the article syntagm is used in the meaning which was used by Scherba, i.e. syntagm is used as a whole which is indivisible from intonation point of view.

Brizgunova who touched the problem of the syntagmatic division of a sentence writes:

"Syntactic partitioning of utterance is, on one side, connected with logical-syntactic structure of sentence, on the other side with the speaker's attitutde to what is said. The partitioning which is conditioned by logical-semantic structure of a sentence is eternal and absolute. However, parsing which is conditioned by the speaker' attitude to utterance is changable and undergoes variation in the same sentence of different speakers." (Brizgunova, 1977). Brızgunova finds such a partitioning ancillary and unimportant. The author considering bigger syntagms main ones writes: "As they express the main partitioning of a thought, it is important to distinguish them" $(56,168)$. According to Brizgunova, minimal and main syntagm notions reflect the main features of syntagmatic partitioning, on one side - partitioning variations, and on the other side dependence of partitioning on syntactic structure of a language, and so it expresses the limitation of partitioning" (Brizgunova,1977).

According to Zinder, "The close relationship between intonation and sentence makes it one of the main factors of communication. ... in order to understand a sentence it is not important to know all the words in it. Context makes it easy to restore the word which is unknown, even if such kind of "restoration" doesn't happen, the understanding of a sentence meaning is not excluded. ... this time intonation plays an important role" (Zinder, 1979). According to Zinder "melody serves to express communicative types of sentence-declarative, interrogative and affirmative more than the other components of intonation" (Zinder, 1979).

Veysalli writes about the role of sentence stress - a main part of intonation in the division of a syntactic whole: “... sentence stress turns a sentence into a whole, ... divides the sentences into syntagms" (Veysalli, 2007). The author uses the scheme below:

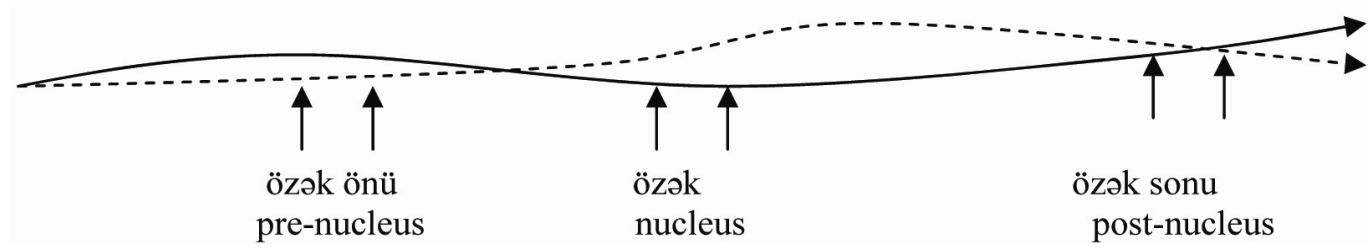

/Səninlə keçirdiyim günlər/şirin xatirələr kimi/həmişə qəlbimdə yaşayacaq// (/The days I spent with you /will live in my heart forever/, as sweet memories//)

1) /Səninlə keçirdiyim günlər/ (başlanğıc sintaqm) (/The days I spent with you/ main syntagm)

2) /Şirin xatirələr kimi/ (orta sintaqm) (/as sweet memories// middle syntagm)

3) /Həmişə qəlbimdə yaşayacaqdır// (terminal sintaqm) (He will live in my heart forever/ terminal syntagm). 


\section{Research Methodology}

As the article is devoted to the elements of two languages belonging to different language families and having different systems, there has been a demand to use different methods, including comparative and experimental methods. In this research we have used comparative typological and experimental-analysis methods in the investigation of comparative analysis of melodic variation of concession clauses with two or more syntagms in English and Azerbaijani.

\section{Experimental Phonetic Analysis of Melodic Variation of Concession Clauses with Two or More Syntagms in English and Azerbaijani}

The learning of variation contour of a sentence can give strong incentive to the solution of variation problem. The main component of melody is in active connection with syntactic structures and a lexical construction. Linguistic and extra-linguistic factors such as the length, synntactic structure, place and the number of different stress types of utterance, intonation-context partitioning, context and condition, psychological condition of the speaker and his intention, as well as individual features of his speech can influence to the realization of variation of intonation. Like other units of language intonation contour can undergo variation, i.e., it can be expressed in either sounding, or in variants, realisations from semantic point of view. The variation of sounding creates intonation types and the variation of intonation contour guarantees the colourfulness of speech.

Yunusov who investigates intonation characteristics of composite complex sentences writes: “... intonation structure of these units is always closely connected with grammar. The intonation structure of composite complex sentences as well as its grammatical characteristics is the expression of general compliance of language functions" (Yunusov, 2008).

In the material which is connected with the solution of the intonation division, both syntactical composition and syntactic structure of syntagms must be paid attention. In this case there should be chosen such sentences that they could express different meanings depending on the division the sentence. In this division the place of the syntagm stress which plays the leading role must be taken into consideration.

In the recording process of the language material, two English and two Azerbaijani speakers' took part. Individual pronunciation deviations of speakers haven't been taken into consideration, on the basis of their concrete results average results have been got and avarege marks have been used in the interpretation of language material.

Composite complex sentences are divided into main syntagms - principal and subordinate clauses. In composite complex sentences with concession clauses which have become complex with numerations, comparisons, explanations, principal and subordinate clause components are characterised by their division into constant syntagms.

The analysis of melodic graph of the English sentence /Though war and danger were in store / war and danger might not befall for months to come// [1ou 'w6: 5nd 'de9nd=7 w8: 9n st6:, 'w6: 5nd 'de9nd=7 ma9t n6t b9'f6:1 f6: $\mathrm{m} 0 \mathrm{n} 4 \mathrm{~s} \mathrm{t} 7 \mathrm{k0m}$ ] (Baxmayaraq ki, müharibə va təhlükə gözlanilirdi, müharibə və təhlükənin baş verməsi aylarla vaxt apara bilardi) shows that the sentence has been divided into two syntagms. Both subordinate clause (progredient syntagm) which is used in preposition, and the principal sentence which acts as a terminal syntagm have independent intonation contour: in both syntagms the melody peak has been registered in the initial syntagm. In the first syntagm melodicy size is $286-186 \mathrm{hs}$, in the second syntagm it is $241-170 \mathrm{hs}$.

In the sentence /War and danger might not befall for months to come /though war and danger were in store// ['w6: 5nd 'de9nd=7 ma9t n6t b9'f6:1 f6: m0n4s t7 k0m, 1ou 'w6: 5nd 'de9nd=7 w8: 9n st6:] (Müharibə və təhlükənin baş verməsi aylarla vaxt apara bilardi, baxmayaraq ki, müharibə və təhlükə gözlanilirdi) the principal clause is used as a progredient syntagm, the subordinate clause acts as a terminal syntagm. Inside the compound whole the position of principal and subordinate clauses doesn't affect the realisation of intonation contour in them. In progredient syntagm melody is $281-187 \mathrm{hs}$, but in the terminal syntagm it is $216-187 \mathrm{hs}$. In the terminal syntagm average absolute value of tone frequency is $170 \mathrm{hs}$. In the initial syntagm avarege tone frequency is $225 \mathrm{hs}$, while in the terminal one it is equal to $204 \mathrm{hs}$. (see Graph 2.1). 


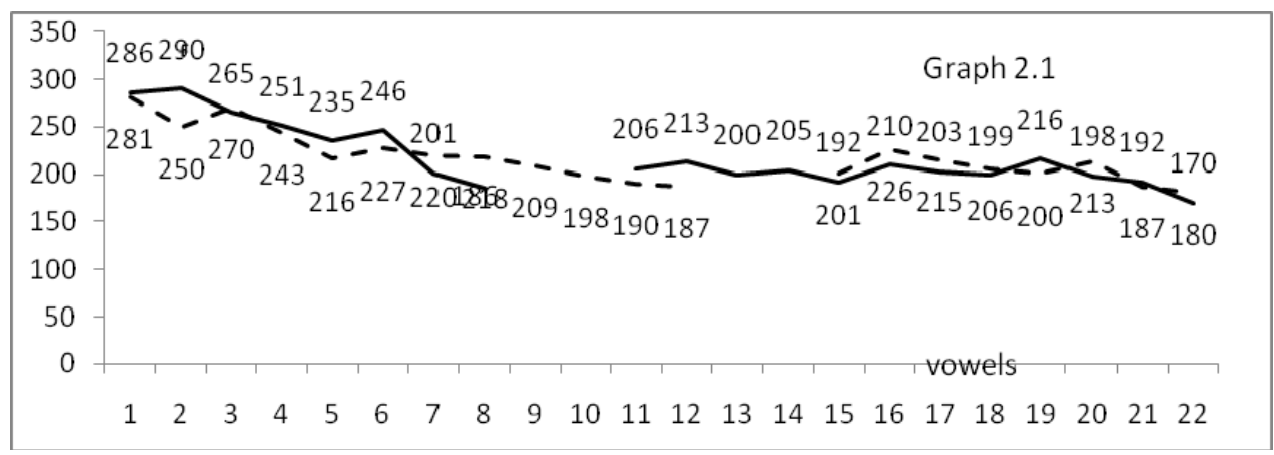

Graph 2.1. Melodic indicators of the sentences

[1 ou `w6: 5nd 'de9nd=7 w8: 9n st6:, ‘w6: 5nd `de9nd=7 ma9t n6t b9' f6:1 f6: m0n4s t7 k0m]

['w6: 5nd `de9nd=7 ma9t n6t b9'f6:1 f6: m0n4s t7 k0m, 1ou ‘w6: 5nd `de9nd=7 w8: 9n st6:]

In the Azerbaijani language the sentences /İndi boz ay olsa da/adamların üzü bahar səması kimi açıq idi// and /Adamların üzü bahar saması kimi açıq idi/indi boz ay olsa da// are two-syntagms. In the first sentence the subordinate clause is in preposition, in the second one it is realised in the postposition. In the first sentence main tone frequency according to syntagms is $276-240 \mathrm{hs}, 252-206 \mathrm{hs}$, in the second one it is $268-198 \mathrm{hs}, 238-208 \mathrm{hs}$. In the analysed sentences melody peak in both syntagms comes in the initial syllable. Melody peak in progredient syntagms is $276-288 \mathrm{hs}$, in terminal syntagms it is equal to $252-238 \mathrm{hs}$. (see Graph 2.2).

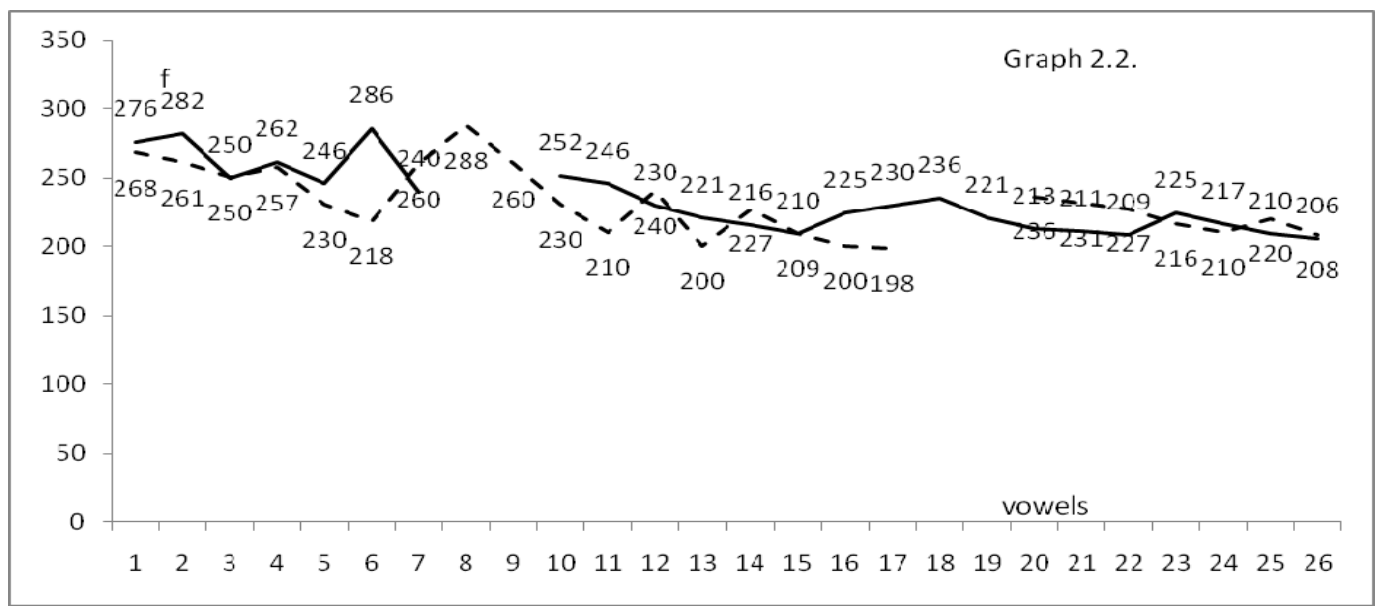

Graph 2.2. Melodic indicators of the sentences

/İndi boz ay olsa da / adamların üzü bahar səması kimi açıq idi//

/Adamların üzü bahar səması kimi açıq idi / indi boz ay olsa da//

In the analysed complex wholes the main tone frequency development can be described as the following:

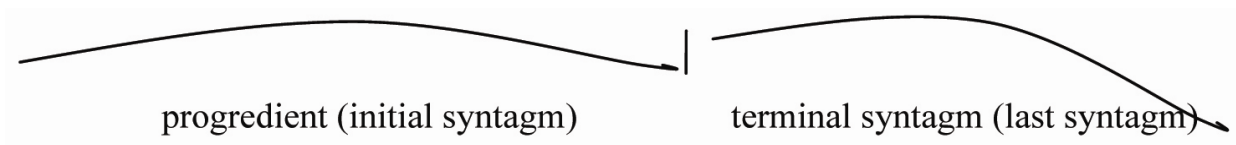

Scheme 2.1. The intonation contour established on the basis of melody indicators in two-syntagm sentences

The main factor in the study of melody contour of compound syntactic whole consisting of two syntagms is the relationship of melodic curves of syntagms to each-other. In relation to the development melody contour in progredient syntagm it is falling, but it doesn't become weaker like in terminal syntagm. In terminal syntagm melody is maximum weaker, which informs that in those syntagms completeness intonation is realized. 
In complex sentences /Lydia, my love, /though you are the youngest / I dare say Mr. Bingle will dance with you at the next ball// [19d9a, ma9 10v, 1ou ju: a: 17 j027st, a9 de7 se9 m9st7 b921 w91 da:ns w91 ju: 5t 17 nekst b6:1] (Lidya, sevgilim manim, baxmayaraq ki, san an gancsən, Canab Binql növbati balda saninla raqs edacək) and ¡Oh! said Lydia stoutly, "I am not afraid; /for though I am the youngest/ I am the tallest// [7-! Sed 19d9a staut19, a9 5m n6t 7 fre9d; f6: 1 ou a9 5m 17 j027st, a9 5m 17 t6:17st] (;Ah! Lidya qatiyyatla dedi, "Mon qorxmuram, baxmayaraq ki, man an gancom, man on ucaboyluyam) the subordinate clause is used in mid-position, and consequently, these sentences are divided into 3 syntagms. In the syntagms of the first sentence melody is 238-188 hs, 246-214 hs (subordinate clause), 216-182 hs (terminal syntagm), in the second sentence the main tone frequency for syntagms is $248-197 \mathrm{hs}, 238-192 \mathrm{hs}$ (subordinate clause), 221-176 hs.

In the following English sentences /We enjoyed our trip, /although the weather was very windy and rainy/ to the mountain// [wi: 9n`d=69d au7 tr9p, 6:1`17u 17 'we17 w7z ver9 w9nd9 5nd re9ni, t7 17 'maunt7n] (Biz sayahətimizdən zövq aldıq, baxmayaraq ki, dağa gedəndə hava küləkli va yağışlı idi); /I think, you, while I admire your courage, ought not to go on this dangerous trip// [a9 492k, ju: wa91 a9 7d 'ma97 j6: 'k0r9d=, ‘6:t n6t t7 g7- 6n 19s 'de9nd=7r7s tr9p] (Düşünüram ki, sən, baxmayaraq ki, mən sanin casaratinə heyranam, bu tahlükali sayahata getmamalisan); there are three syntagms. In the sentences minimum tone frequency is registered at the end of the terminal sentence: $175-176-182 \mathrm{hs}$. Melody according to syntagms has the variation in the following diaposones: 1 st sentence $236-210 \mathrm{hs}, 245-197 \mathrm{hs}, 217-175 \mathrm{hs}$; 2 nd sentence 242-210 hs, 231-205 hs, 230-176 hs.

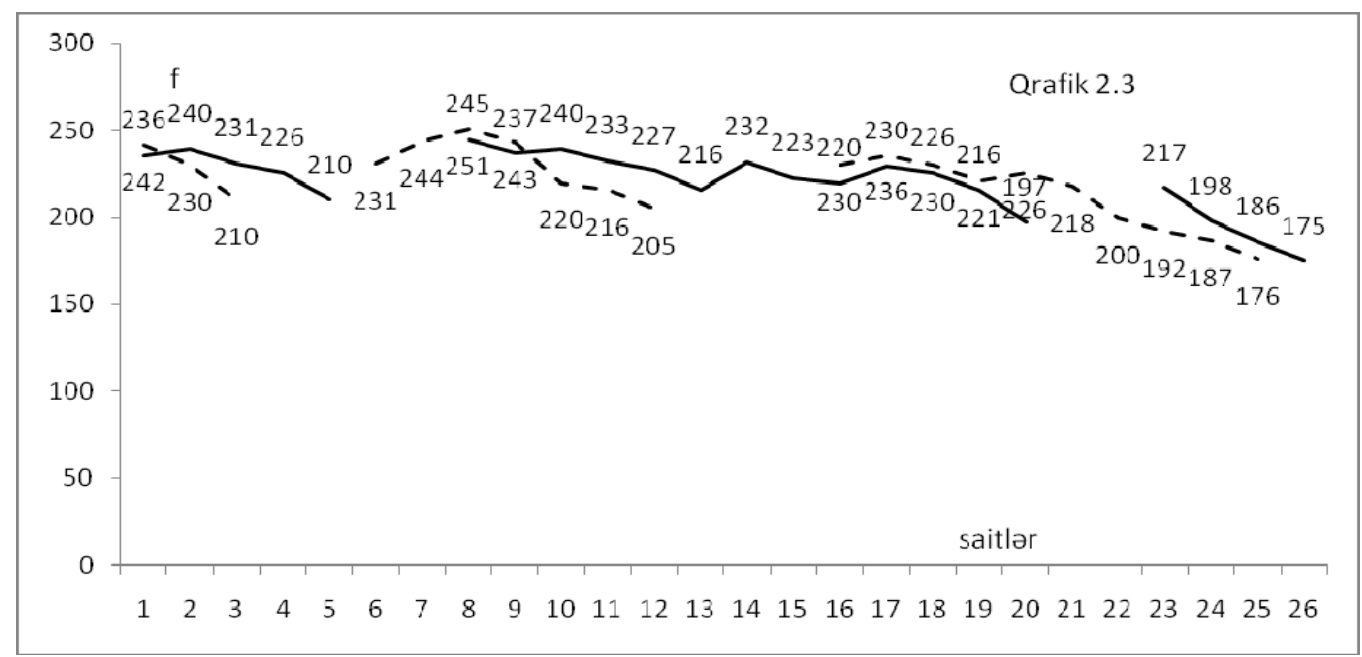

Graph 2.3. Melodic indicators of the sentences

[wi: 9n`d=69d au7 tr9p / 6:1`17u 17 `we17 w7z ver9 w9nd9 5nd re9ni / t7 17 `maunt7n]

[a9 492k, ju:/wa9l a9 7d`ma97 j6: `k0r9d=/`6:t n6t t7 g7- 6n 19s `de9nd=7r7s tr9p]

In the multi-syntagm sentences /Lakin gənc işdən çıxmadl, çünki satıcı deyingən olsa da / düz adam idi / və sözünün üstündə dururdu// and /Görürsünüz / Casuru nə qadər özünüzdən uzaq tutmaq istasəniz də / ya özü / ya da onu xatırladacaq insanlar qarşınıza çıxır// the syntagm consisting of subordinate clause is used in mid-position. Osillographic analysis shows that in the syntagms of these sentences main tone frequency is expressed by means of above given indicators: the 1st sentence 369-212 hs, 354-276 hs, 305-211 hs, 228-187 hs; the 2 nd sentence 293-236 hs, 306-216 hs, 220-210 hs, 215-190 hs (see scheme 2.2).

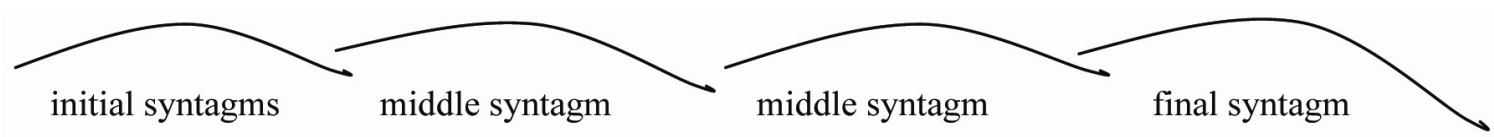

Scheme 2.2. Intonation contour established on the basis of melody indicators in multi-syntagm sentences 


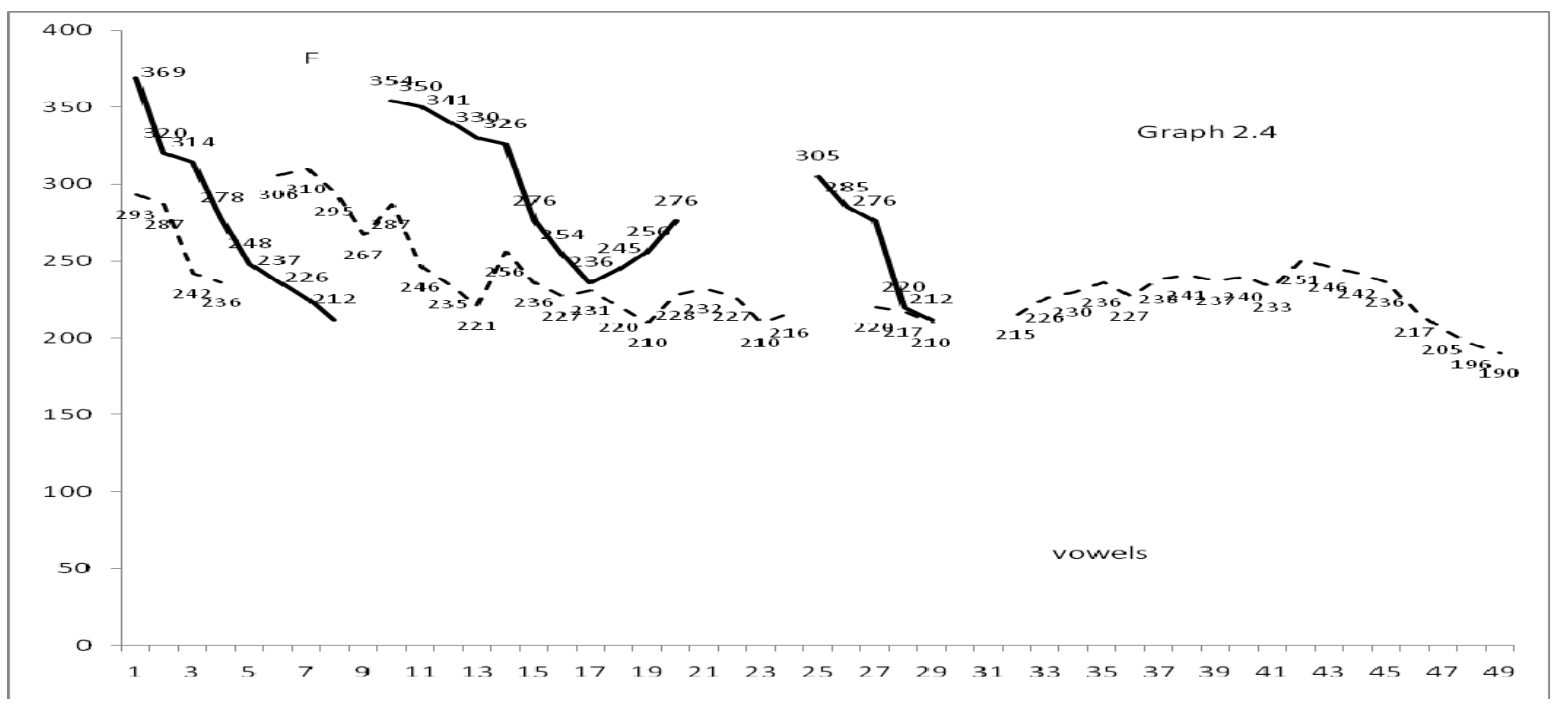

Graph 2.4. Melodic indicators of the sentences

/Lakin gənc işdən çıxmadı, çünki satıcı deyingən olsa da/düz adam idi//

/Görürsünüz/Cəsuru nə qədər özünüzdən uzaq tutmaq istəsəniz də/ya özü/ya da onu xatırladacaq insanlar qarşınıza çıxır//

The sentences, /I tried hard/though it seemed impossible/to complete the task// [a9 tra9d ha:d, 1ou 9t s9:md 9m ’os9bl, t7 k7m pli:t 17 ta:sk] (Mon ciddi çalışdım ki, işi tamamlayım, baxmayaraq ki, bu qeyri-mümkün görünürdü// and /Though it seemed impossible/I tried hard to complete the task// [1ou 9t s9:md 9m pos9bl/a9 tra9d ha:d t7 k7m pli:t 17 ta:sk] /Baxmayaraq ki, bu qeyri-mümkün görünürdü, mən ciddi çalışdım ki, işi tamamlaym) in the 1st case, contain three, in the 2nd case two syntagms. The initial syntagms of the 1st sentence are equal to 51-200 hs, the syntagms consisting of subordinate clause are 30-190 hs, the terminal syntagm is 224-203 hs-dir, but in the sentence [1 ou 9t s9:md 9m pos9bl/a9 tra9d ha:d t7 k7m pli:t 17 ta:sk] the main tone frequency according to syntagms is distributed like: 259-195 hs, 208-189 hs.

In the sentences /They all returned from him to you / though they were mine before// [1e9 6:1 r9` t8:nd fr6m h9m t7 ju:, 1ou 1e9 w8: ma9n b9'f6:] (Onlar hamisı ondan sənə qayltdllar, baxmayaraq ki, avvallar onlar manim idilar) and /Though they were mine before/they all returned from him to you// [1ou 1e9 w8: ma9n b9'f6:, 1e9 6:1 r9't8:nd fr6m h9m t7 ju:] (Baxmayaraq ki, avvallar onlar manim idilar, onlar hamisl sana qayitdilar) the subordinate clause is used in the structure of complex sentences and in pre- and post positions. In the first sentence syntagms the main tone frequency is $225-207 \mathrm{hs}, 210-166 \mathrm{hs}$, in the second sentence it is equal to 273-214 hs, 216-175 hs. The melody peak falls on the beginning of the progredient syntagms in these sentences: $238 \mathrm{hs}$ and $282 \mathrm{hs}$. In progredient syntagms of both sentences melody begins from middle register, it has relatively risen towards the middle, and at the end it has moved in the falling direction. However, at the end of progredient syntagms the weakening of melody doesn't fall like in terminal syntagms. In these analysed sentences melody among syntagms is characterised by positive intervals, i.e., the melody used at the end of previous syntagms is relatively lower than the melody used at the beginning of the following syntagm (see scheme 2.3. a).

The English sentences /Even had he been able to make his lips move / the man would not have understood him// ['i:v7n h5d hi: bi:n e9bl t7 me9k his 19pz mu:v/17 m5n w-d n6t h5v^0nd7`st-d h9m] (Dodaqlarinı tarpadə bilmayə müvaffaq olsaydı bela, kişi onu başa düş̧ bilmazdi) and /If she got no money from her brother-in-law,/ she got what was as good as money-credit// [9f 3i: g6t n7 m0ni fr6m h8: 'br017-9n-16:, 3i: g6t w6:t w7z 5z g-d $5 \mathrm{z}$ m0ni- 'kred9t] (Hatta o qayınından pul ala bilmadisa bela, o, pul krediti kimi yaxşı olan istadiyi har şeyi aldı) which have been involved to oscillographic analysis, melody according to syntagms has been distributed like this: in the 1st sentence 268-218 hs, 194-178 hs; in the 2nd sentence 230-215 hs, 200-173 hs. 


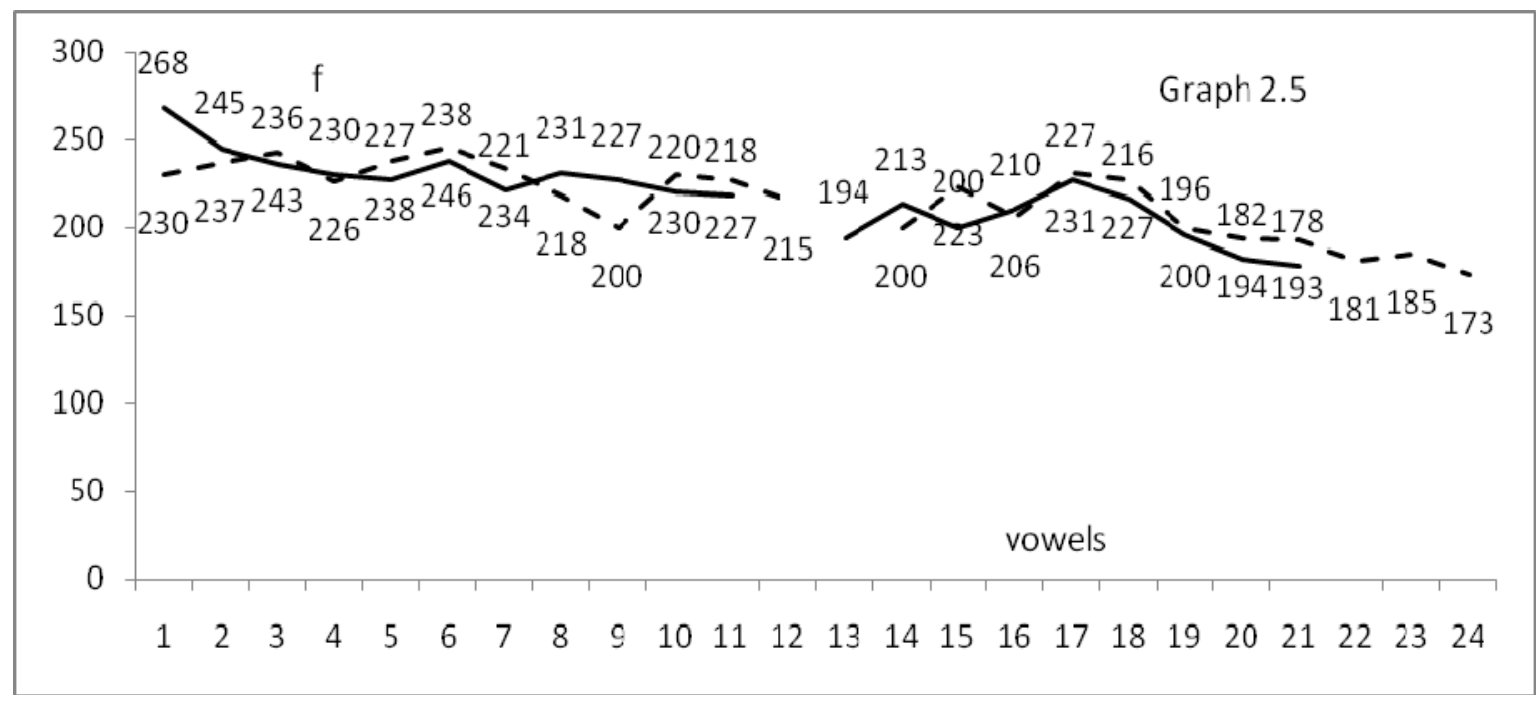

Graph 2.5. Melodic indicators of the sentences

['i:v7n h5d hi: bi:n e9bl t7 me9k his 19pz mu:v / 17 m5n w-d n6t h5v^0nd7`st-d h9m]

[9f 3i: g6t n7- m0ni fr6m h8: ’br017-9n-16: / 3i: g6t w6:t w7z 5z g-d 5z m0ni-'kred9t]

The results of the experiment reveal that in multi-syntagm complex constructions maximum acoustic indicators are registered in initial syntagms: $268 \mathrm{hs}, 260 \mathrm{hs}, 237 \mathrm{hs}$. However, in the analyzed sentences at the end of the initial syntagms melody indicators are higher than the beginning melody of the following syntagm, i.e., a negative interval is not registered in them. (see scheme 2.3. b).

We can case the analogical situation in the melody parameters of the following examples taken from Azerbaijani: /Uşaqlar nə qadər xahişs etdilarsa da / Hasən dayı razı olmadı//, /Dünya dăğlsa da/mən o şarti qabul etməуасәуәт//. In the 1st sentence melody according to syntagms is $291-301 \mathrm{hs}, 286-195 \mathrm{hs}$; in the 2 nd sentence 293-283 hs, 265-197 hs, 216-182 hs.

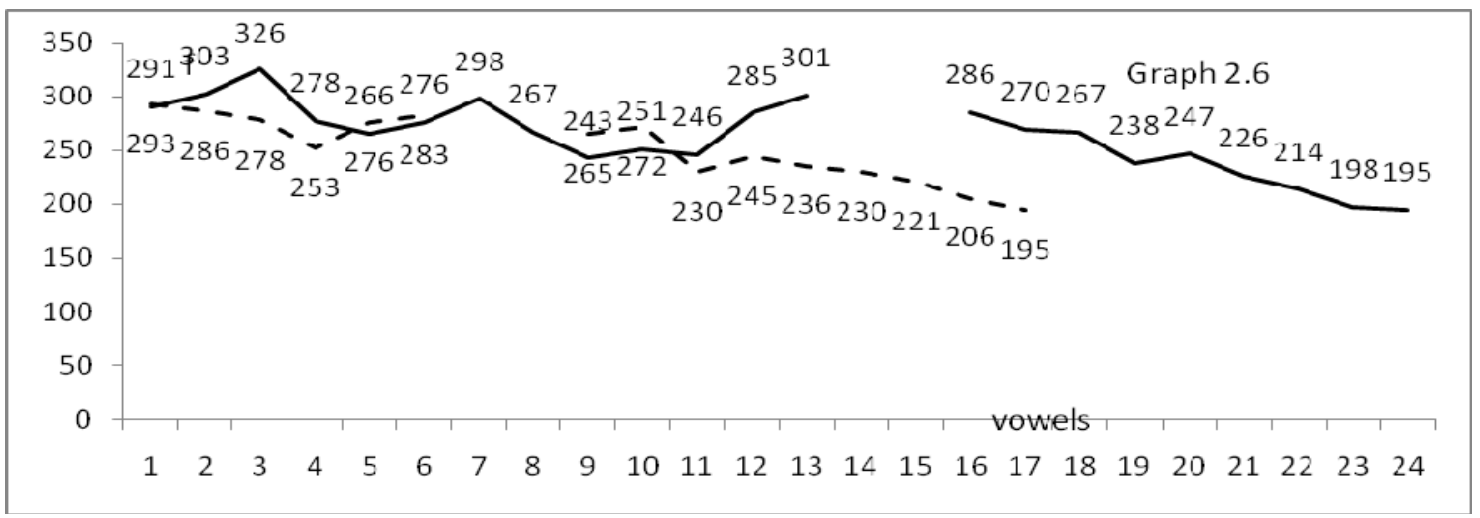

Graph 2.6. Melodic indicators of the sentences

/Uşaqlar nə qədər xahiş etdilərsə də / Həsən dayı razı olmadı//

/Dünya dağılsa da /mən o şərti qəbul etməyəcəyəm//
a) positive interval
b) negative interval

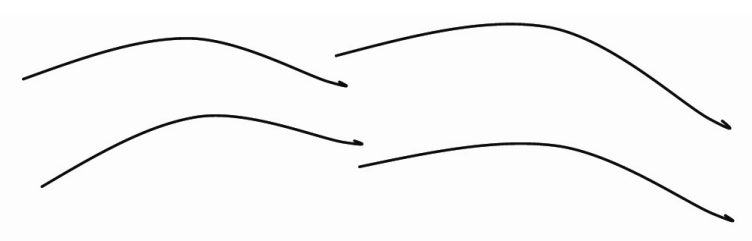

Scheme $2.3 \mathrm{a}, \mathrm{b}$ 
The results that we got coincide with the viewpoint of Aslanov, who has investigated intonation features of multi-syntagm sentences in Germanic and Azerbaijani. The author writes that "according to the analysis of the melodic and dynamic structures of multi-syntagm sentences, the acoustic indicators of initial syntagms are in maximum level, but the appropriate indicators of the final syntagm are in minimum level. The melodic and dynamic structure of the middle syntagm changes between the appropriate parameters of the first and last ones". (Aslanov, 2009).

In the composite complex sentences /Hara gedir-getsin/məndən yaxşısını tapa bilməyəcək// - /Məndən yaxşısını tapa bilməyəcək / hara gedirsa-getsin// the syntagms coincide with principal and subordinate clauses. The analysis of melodic curves of the sentences is accompanied by the rising-falling tone in the progredient syntagms, and in the terminal syntagms it is expressed by the gradual fall of melody. In the analysed sentences in progredient syntagms the melody faces variation with $337-256 \mathrm{hs}, 391-311 \mathrm{hs}$, in the terminal syntagms $270-197$ hs, 284-196 hs.

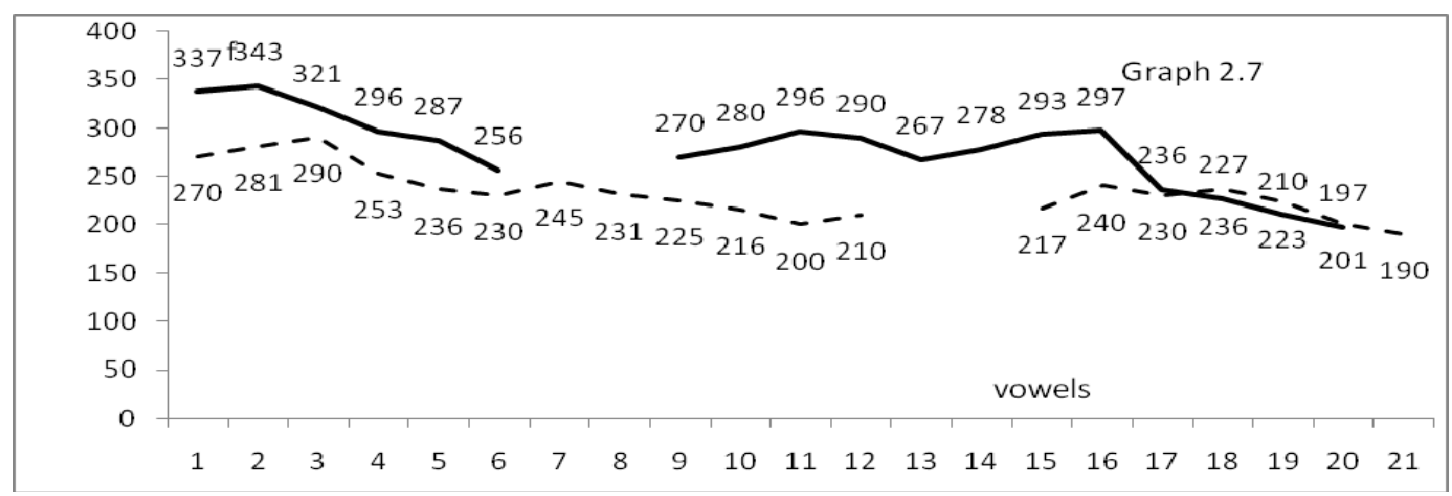

Graph 2.7. Melodic indicators of the sentences

/Hara gedir-getsin / məndən yaxşısını tapa bilməyəcək//

/Məndən yaxşısını tapa bilməyəcək / hara gedirsə-getsin//

The subordinate clause component of the sentence /Even if he were here,/ he couldn 't help us// [`i:v7n 9f he w8: h97/hi: k-dnt help 0z] (Hatta o burada olsaydı bela, o bizə kömək edə bilmazdi) acts as a progredient syntagm. The melody of this sentence according to syntagms is expressed by the following indicators: in the 1st sentence 223-203 hs, 231-183 hs. In the subordinate clause component of the sentence, which is used in proposition, /They will go /even ifleven though you prohibit them to// [1e9 w91 g7-/ `i:v7n 9f/ i:v7n 17- ju: pr7`h9b9t 1em t7] (Hotta san qadağan etsan bela onlar gedacəklar) melody according to syntagms is expressed with the following indicators: in the 1st sentence $250-238 \mathrm{hs}, 238-181 \mathrm{hs}$; in the 2 nd sentence $264-202 \mathrm{hs}, 228-288 \mathrm{hs}$.

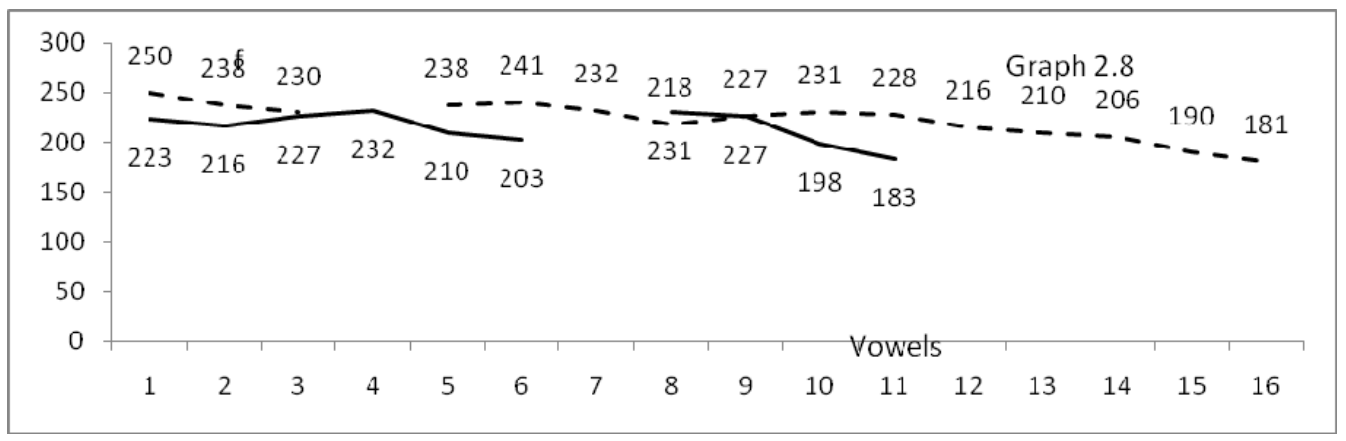

Graph 2.8. Melodic indicators of the sentences

['i:v7n 9f he w8: h97 / hi: k-dnt help 0z]

[1e9 w91 g7-/ 'i:v7n 9f/`i:v7n 17- ju: pr7`h9b9t 1em t7]

Melodic features of such two-syntagm sentences was also described by Scherba:

"The last syllable of the first part is sure to be pronounced with rising tone, but the second part, in whole, is in the falling direction" (Scherba, 1974). The falling melody inside the syntagm informs about the completeness of 
the utterance. According to Zinder "... considerable falling at the end of the part informs us about either the syntagm's having independent meaning and syntactic unit, or shows that any compound sentence is completed." (Zinder, 1979).

The main feature of the sentences whose melodic parameters have been analysed is that in comparison with the terminal syntagms the initial (progredient) syntagms possess high indicators. Another general feature is that maximum tone frequency is used at the beginning of syntagms.

\section{Conclusion}

Experimental analysis of the materials of the compared English and Azerbaijani languages helps us to come to the following conclusions:

While comparing the sentences from Modern English and Azerbaijani, which have been involved in the experiment, it becomes evident that intonation contour development of complex constructions (in which subordinate clause component is realised) in preposition doesn't strongly differ from those which are used in postposition.

Even the analysis of the acoustic indicators of three parameters (temporal, melody, dynamic parameters) show that in the analysed sentences, in comparison with the terminal syntagms, progredient syntagms are pronounced with higher melodicy. This fact proves that both in progredient and terminal syntagms the intonation of completeness is not realised. The cadence law which demands the weakening of acoustic parameters at the end of the syntagm is reflected in the investigated examples.

In the conclusion, while investigating intonation features composite complex sentences with concession clauses in both languages the followings have become evident: intonation has a certain autonomy, i.e., its emergence, realization doesn't depend on concrete lexical material and certain syntactic structure, and the place of the components of compound syntactic whole. Just the very autonomy of intonation gives a chance to the same intonation contour to appear in different syntactic constructions and sentence types.

\section{References}

Aslanov, F. A. (2009). The problem of syntagm in modern German and Azerbaijani and its experimental-phonetic analysis. Baku: Nurlan.

Brizgunova, E. A. (1977). Sounds and intonation of Russian Speech. Moscow: Visshaya Shkola.

Peshkovskiy, A. M. (1960). Intonation and Grammar. Selected works. Moscow: Visshaya Shkola.

Scherba, L. V. (1958). Experiment of general theory of lexicography. Leningrad: Nauka.

Scherba, L. V. (1974). Language system and speech activity. Leningrad: Nauka.

Veysalli, F. (2007). Language. Baku: Maarif.

Yadigar (Veysalli), F. (1993). Problems of phonetics and phonology. Baku: Maarif.

Yunusov, D. (2008). Constancy and variation in complex syntactic units. Baku: Nurlan.

Zinder, L. P. (1979). General Phonetics. Moscow: Visshaya Shkola.

\section{Copyrights}

Copyright for this article is retained by the author(s), with first publication rights granted to the journal.

This is an open-access article distributed under the terms and conditions of the Creative Commons Attribution license (http://creativecommons.org/licenses/by/3.0/). 